\title{
MedienPädagogik
}

Zeitschrift für Theorie und Praxis der Medienbildung

\section{Mobilities and Ecologies: Reflections on Paradigms for Mobile Learning}

\author{
Theo Hug
}

\begin{abstract}
Mediated lifeworlds and a diversity of physical, geographical, technological, cultural, and social mobilities involve new challenges for education and learning in a digital age. In recent years, a variety of corresponding conceptualizations and methods has been developed in educational research and practice. One the one hand, we find technologically or culturally abridged concepts and reductionist approaches, more or less dealing with one category or dimension of the topic. On the other hand, there are ambitious approaches dealing with the enormous complexities of the issues concerned. The latter frequently refer to ecological or mobilities frameworks. Moreover, among the many (turns〉 that have been claimed after the linguistic turn, especially the ecological turn and the mobilities turn play an important role in the context of theorizing mobile learning and education. For one thing, a new mobilities paradigm has been proposed, then again various ecological approaches have been promoted, among them media ecologY, information ecologY, knowledge ecologY, socio-cultural ecologY, communicative ecologY, political ecologY, and ecologies of affect. In addition, there are different understandings of ecology, for example, as environment, social movement, moral norm, or network theory. The paper reflects on potentials and limitations of mobilities and ecologies as theoretical frameworks in the context of mobile learning.
\end{abstract}




\section{Mobilitäten und Ökologien: Überlegungen zu Paradigmen für mobiles Lernen}

\section{Zusammenfassung}

Medialisierte Lebenswelten und die Vielgestaltigkeit physischer, geografischer, technologischer, kultureller und sozialer Mobilitäten stellen neue Herausforderungen für Bildung und Lernen im digitalen Zeitalter dar. In den letzten Jahren wurden in der Bildungsforschung und -praxis eine Vielzahl einschlägiger Konzeptualisierungen und Methoden entwickelt. Einerseits finden wir technologisch oder kulturell verkürzte Konzepte und reduktionistische Ansätze, die sich hauptsächlich mit einer Kategorie oder Dimension des Themas befassen. Andererseits gibt es ambitionierte Ansätze, die sich mit der enormen Komplexität der Thematik befassen. Letztere beziehen sich häufig auf Paradigmen der Ökologie oder Mobilität. Weiters spielen unter den vielen (Wenden), die nach dem linguistic turn proklamiert wurden, vor allem die ökologische Wende und die mobile Wende eine wichtige Rolle im Kontext der Theorie des mobilen Lernens. Zum einen wurde ein neues Mobilitätsparadigma vorgeschlagen, zum anderen wurden verschiedene ökologische Ansätze entwickelt, darunter Medienökologie, Informationsökologie, Wissensökologie, soziokulturelle Ökologie, kommunikative Ökologie, politische Ökologie und Affektökologie. Dabei bestehen unterschiedliche Auffassungen von Ökologie, z.B. als Umwelt, soziale Bewegung, moralische Norm oder Netzwerktheorie. Der Beitrag reflektiert Potenziale und Grenzen paradigmatischer Aspekte von Mobilitäten und Ökologien im Kontext des mobilen Lernens.

\section{Digitization, Mediatization and Medialization: Some Points of Departure}

Mobile learning has become a field of didactic, educational, psychological and technological research that is particularly relevant to formal and informal learning contexts. Today, we find various conceptualizations of 〈mobile learning〉 in academic writings, educational policy papers, and application-oriented documents. As in other educational and societal contexts in general, keywords such as (digitization) and (mediatization〉 are often referred to in respective introductory framings. Sometimes, there is 
also talk of 〈digital education〉 and, in analogy to 〈Industry 4.0〉, of 〈Learning 4.0〉, 〈School 4.0〉, 〈University 4.0〉 and 〈Humanities 4.0〉, too.

These framings and ways of expression are meant as markers for enhanced perspectives and new key focal areas. On closer examination, however, they turn out to be abbreviated or one-sided forms of representation that are more relevant with regard to purposes of conceptual, educational and funding policy than in the context of educational and media science research. Even where the belief in calculability and predictability of the world knows hardly any limitations, it would have to be conceded that the conceptualization of 〈education> (Bildung) as a functional moment in an ensemble of quantifying infrastructures would come down to calculable forms of self-determination, cultural meaning-making and sense-giving, situated and contextualized knowledge of connections, social responsibility, creative design, aesthetic perception or emancipatory development.

As is well known, the reference to a fourth industrial revolution, which was linked by the German Federal Government to the code 44.0$\rangle$ in connection with the development of a high-tech strategy, aims at a profound change in production, business and value-added processes and at the creation of highly complex, networked structures in which (partially) autonomous people and machines as well as digital technologies and cyberphysical systems (CPS) interact in a result-oriented and profitable manner. Correspondingly, mobile learning in this perspective would result in a mode of digital fluency in automated and program-controlled learning environments. Such environments could function, for example, as part of 〈social physics〉 in the sense of the homonymous research group at the MIT Media Lab (http://socialphysics.media.mit.edu) based on expectations of individual and collective functionality, assimilation and subordination in mobilized societies.

If, however, we refer to all socio-cultural dynamics of change and transformation that somehow have to do with the spread and increasing use of digital technologies as (digitization), then significant dynamics at the interfaces of media, cultural, social and technological developments are not adequately brought into focus. With regard to media cultural practices, co-evolutionary dynamics, and changing media-historical constellations, these intertwined dynamics are better described by terms like 
〈medialization〉 and 〈mediatization〉. Traditionally, the term 〈mediatization〉 has been used in contexts of enforced loss of immediacy, originally in feudal contexts and the final years of the Holy Roman Empire when various self-ruling entities lost their independent status (〈imperial immediacy〉). In my view, it makes sense to use the term for all forms of medial enforcement and not only for examples of the subsumption of an immediate (unmittelbar) state into another state, thus becoming mediatized or mediate (mittelbar). As for mobile learning, an example would be the implementation of (smart) learning environments in educational institutions as part of digitization strategies, compulsory for teachers and students, aiming at flexible and mobile learning anytime and anywhere while at the same time fostering non-transparent learning analytics.

This take on media as «a kind of colonizing force undermining an independent social system with their contagious media logic» (Adolf 2011, 155; italics in original) should not be mixed up with complementary terms like 〈medialization〉 and 〈conveying〉 or 〈mediation〉 (Vermittlung). Media as part of co-evolutionary dynamics are not necessarily enforcing specific media communicative, socio-cultural or institutional changes. Processes of medialization may refer to changing media constellations and media-cultural transformation, to co-constitutive potentials of media for various forms of articulation, to changing uses of technical media or semiotic means of communication (for example, image, language, or writing), or to the enabling of changing media practices.

Medialization of knowledge, for example, can refer to changing forms of the production, representation, description, reflection, analysis, assessment and critique of knowledge by semiotic means of communication (for example, textualization or visualization) or by application of media technologies of production, storage and transmission. It can also refer to medial extension of natural or cultural boundaries of human capacities, to medial augmentation or incorporation of knowledge, or to new medial forms and forms of sociotechnical integration of knowledge. Corresponding dynamics which can be long-term or short-term are rather related to conditions of enabling and not inevitably geared to the enforcement of specific media offers, agencies or structures. 
In the discourse history of mobile learning, in addition to the technologically accentuated or abridged variants, more differentiated forms of thematization play a role, in particular in connection with references to mobilities and ecologies as theoretical frameworks.

\section{Mobile Learning: From Technological Simplifications to Complex Understandings}

Phenomena of mobile learning avant la lettre can be traced back throughout human history. The term 〈mobile learning〉 (m-learning) has been used for about 20 years, mainly in learning technology and educational policy discourse contexts, sometimes also in educational research. Until today, there is no commonly accepted definition available. Quite often, definitions have been created around technical issues or as a sub-domain of e-learning. Clark Quinn (2000), for example, defined m-learning at the

«intersection of mobile computing and e-learning: accessible resources wherever you are, strong search capabilities, rich interaction, powerful support for effective learning, and performance-based assessment. e-learning independent of location in time or space» (ibd., 1).

Similar definitions focusing on making use of mobile computational devices for learning purposes are widespread until today, especially in the context of business applications and commercially oriented applied research.

In academic discourses more differentiated understandings of $\mathrm{m}$ learning and complex conceptualizations have been taken into consideration (cf. Pachler u.a. 2010; Berge and Muilenburg 2013; de Witt and Gloerfeld 2018). Correspondingly, related discourses are not primarily about mobile technologies or portable devices but, for example, about the "process of coming to know through conversations across multiple contexts amongst people and personal interactive technologies》 (Sharples, Taylor, and Vavoula 2007, 225). At the same time, the idea is rejected that mobile learning is about delivering content to mobile devices. It is rather 
«about the processes of coming to know and being able to operate successfully in, and across, new and ever changing contexts and learning spaces. And, it is about understanding and knowing how to utilise our everyday life-worlds as learning spaces» (Pachler u.a. 2010, 6).

In her historical overview of mobile learning, Helen Crompton provided a useful definition, too. She defines mobile learning as «learning across multiple contexts, through social and content interactions, using personal electronic devices» (Crompton 2013, 4). If we want to take historical and systematic interests into account, a slightly modified definition could serve at least as a working definition for multiple purposes: «Mobile learning is learning across multiple contexts, through social and content interactions, using mobile devices》 (Hug 2015, 491; italics in original). This definition can be used as a starting point for the analysis of a wide range of phenomena including social and religious learning with the Pauline epistles, learning in the context of field trips and excursions, educational use of all sorts of handheld devices in formal and informal learning contexts, and processes of embodiment when using data glasses as well as augmented learning.

\section{Ecologies and Mobilities: Complementary or Incompatible Turns?}

Mediated lifeworlds and a diversity of physical, geographical, technological, cultural, and social mobilities involve new challenges for education and learning in a digital age. As for mobile learning, well-known educational paradoxes continue to be significant. Among them we find areas of tension such as the following: freedom and coercion, external determination (heteronomy) and self-determination, uniformity and diversity, mobilization and stabilization, or proximity and distance. In addition, new paradoxes and ambivalences have become significant, too. The following aspects are given here as examples:

- 〈naturalization〉 of digital media and manifold modes of construction of media environments,

- pleas for open forms of learning and non-transparent forms of learning analytics, 
- opening up towards global dynamics of development and media-cultural imperialism,

- individualized learner-orientations and collective forms of subjectivation in mobile learning contexts,

- growing calls for educational adaptation and agility, but getting stuck in a rhetoric of learning and implementation of learning technologies in educational institutions which continue to be shaped in the light of book cultural perspectives,

- calls to develop flexibility and new learning cultures while at the same time cultivating techno-communicative and administrative constraints,

- promoting mobile medial extensions and leaving medial embodiment processes as blind spots.

The list could be continued. It is not surprising that in view of related areas of tension and complexities there is a quest for appropriate and viable frameworks. Given such complex and paradoxical constellations, we find ecologies and mobilities among the most promising candidates for useful theoretical frameworks. On the one hand, both of them have been developed in many respects and they are compatible with meta-theoretical, theoretical and applications-oriented or practical levels. On the other hand, high degrees of elaboration go hand in hand with claims of a (turn).

\section{Ecologies and the Ecological Turn}

As regards the matter, dealing with communication systems as environments is as old as dealing with cave paintings (cf. Krippendorf 1994). Academic questions of how media, technology, and communication are related and how they affect human environments have been introduced by Marshall McLuhan in the 1960s. While the term «media ecology〉 was first introduced by Neil Postman in the late 1960s, an ecological turn has been described more recently by Bachmair, Pachler, and Cook (2011).

In their comprehensive volume on Mobile Learning: Structures, Agency, Practices, Pachler u.a. (2010) describe the 〈mobile complex〉 as an «exciting infrastructure in flux» (ibd., 11) and as a "conceptual model in which 
educational uses of mobile technologies are viewed in ecological terms as part of socio-cultural and pedagogical contexts in transformation» (ibd., 25). Accordingly, their approach is based on an «ecological interpretation of resources within a cultural frame» (Bachmair, Pachler, and Cook 2011, 5) and on a critical view on economic orientations of the mobile complex (ibd.).

«We see it as our task to show that this economic orientation of the mobile complex as well as of education are not the only possibilities. The former, the mobile complex, we see facilitating a wide range of human activities, in particular self-representation, target-orientated endeavours and play. The latter, formal education we see as being fundamentally about broad and balanced opportunities for child development. This partial rejection of the economic imperative behind mobile learning and formal education we term the 〈ecological turn〉.» (ibd., 4)

Similar like other theoretical concepts of ecologies of media, information, or knowledge, their concept of a socio-cultural ecology aims at bridging divides of humanities and natural sciences in media and educational studies. It is based on a "triangle model of socio-cultural development with the three nodes of societal and technological structures of the mobile complex, user agency and the cultural practices of media use and learning» (ibd., 5). Therefore, it can be connected with both, theoretical work and educational practices, and it can be fruitfully harnessed for bridging different ecological spheres like practices of media acquisition and (mobile) learning in formal and informal contexts (cf. Rummler 2014).

\section{Mobilities and the Mobility Turn}

If we define mobile learning as learning across multiple contexts, through social and content interactions, using mobile devices, interdependencies of various mobilities, a complex interplay of micro, meso and macro levels of learning may well be assumed. As for the relevance of social structures in learning and education, it is obvious to consider perspectives thinking beyond traditional sociological perspectives and discussing issues of a ppostsocietal era), too, in this context. Urry, for example, in his Sociology beyond Societies (2000) presents a 
«manifesto for a sociology that examines the diverse mobilities of peoples, objects, images, information and wastes; and of the complex interdependencies between, and social consequences of, these diverse mobilities» (ibd., 1).

A new transdisciplinary field of mobilities research has been emerging that

«encompasses research on the spatial mobility of humans, non-humans, and objects; the circulation of information, images, and capital; as well as the study of the physical means for movement such as infrastructures, vehicles, and software systems that enable travel and communication to take place» (Sheller 2014, 791).

In the context of a new mobilities paradigm, «hybrid systems of «materialities and mobilities), that combine objects, technologies, and socialities, and out of those distinct places are produced and reproduced» (Sheller and Urry 2006, 214). Consequently, the authors are proclaiming a mobility turn that is "post-disciplinary, beyond the individual separate disciplines and concerned with the multiple ways in which economic, social and political life is performed and organized through time and across many complex spaces» (Urry 2012) - or as Mimi Sheller argues:

«[...] the new mobilities paradigm furthered the spatial turn in the social sciences in many crucial ways because of the ways in which it called for new methodologies and generated novel multidisciplinary assemblages of empirical and applied research, and even a move towards artistic research creation.» (Sheller 2017, 634)

Undoubtedly, this post-disciplinary paradigm turns out to be useful and important for theorizing and designing mobile learning as well as for the application of related concepts. 


\section{Discussion}

Apart from the fact that since the second half of the 2oth century, we find a constantly rising number of proclamations of turns (cf. Aßmann u.a. 2017) questions regarding potentials and limitations of these theoretical frameworks arise. Both, 〈ecology〉 and 〈mobility〉 can be taken as theoretical frameworks and post-disciplinary concepts that enable and foster endeavors of bridging manifold fields of research and application in order to deal appropriately with complex problem situations. At that, normative dimensions as related to contemporary issues of sustainable development and climate disasters, mobility injustice and migration conflicts, or inequality of opportunities and comprehensive surveillance are taken into consideration, too (cf. Sheller 2017, 634).

As comprehensible theoretical frameworks ecology and mobility refer to concretely specifiable phenomenal domains. As productive metaphors they are suitable for the understanding of contemporary, mobile and mediated social life and not least for the study of manifold aspects of mobile learning. Furthermore, they suggest the development of new methodologies and they offer innovative perspectives inside and outside academic worlds, cross-over combinations of different disciplinary approaches, and transversal reasoning.

In my view, ecology and mobility are complementary concepts. However, further clarification of the concepts and conceptual relations is needed. Even though the authors quoted above attach importance to conceptual clarifications a number of limitations and critical aspects should be discussed, too.

Ecology and mobility can count on positive connotations, but passing fad might be an issue if problem-solving capacities are not evinced in comprehensible ways. This also concerns the demarcation of superficial uses of the terms as «umbrella terms or shimmering codes with all-embracing interests, oscillating between all and nothing, or implicitly and involuntarily supporting neoliberal ideologies or techno-bureaucracy.

The fact that such considerations are not easily dismissed is shown by the fact that there are various understandings of 〈ecology〉, for example, as environment, social movement, moral norm, networked relations or systems theory. Moreover, similar to the case of the 〈literacification` of 
(nearly) everything, there are diverse terminological applications like the following:

Media ecology, information ecology, knowledge ecology, socio-cultural ecology, communicative ecology, community ecology, ecosystem ecology, general ecology, human ecology, historical ecology, mental ecology, philosophical ecologies, microbial ecologies, environmental microbiology, molecular ecology, political ecology, postcolonial ecologies, feminist ecologies, border ecologies, design ecologies, educational ecologies, hybrid ecologies, liberation ecologies, infrastructural ecologies, listening ecologies, new documentary ecologies, symbolic ecologies, wild ecologies, ecologies of affect, ecologies of innovation, screen ecologies, ecology of ideas, ecology of materials, ecology of leadership, ecologies of power, ecology of sense, ecology of scale, ecologies of sharing, etc.

Inflationary uses of 〈ecology〉 and 〈mobility〉 in the sense of an 〈ecologization〉 of everything or a 〈mobilization〉 of everything are rather part of problems than of solutions. We should be aware that metaphors can broaden or open up horizons and enable shifts of perspectives but at the same time they can also create blind spots. As serious paradigmatic shifts, both, the mobility turn and the ecological turn, demand further clarification as related to normative and descriptive issues. Moreover, there is a need for clarification of complex interaction of processes of mobilization and stabilization, of holistic and particularistic views, and of relations of a «general ecology» (Hörl and Burton 2017) and epistemologies of 〈regional〉 ecologies.

\section{Challenges for Researching Mobile Learning}

Along with conceptual, methodological and epistemological clarifications, tasks of explaining and illustrating the relevance of complex understandings of mobile learning beyond the use of apps and the promotion of technical user knowledge remain. Some useful contributions on viable frameworks, methods and research designs for the investigation and evaluation of mobile learning have been published already 10 years ago (cf. Vavoula, Pachler, and Kukulska-Hulme 2009). As for future directions, the metatheoretical considerations in this chapter suggest further developments in qualitative and quantitative terms. Especially case studies are in demand 
that illustrate how the interplay of physical, geographical, technological, cultural, and social mobilities works, how environmental agencies come into play, and how ecologization and mobilization of thinking are at work in research as well as in professional and amateur contexts. The focus of the studies can be on individual, organizational, generational or societal dimensions of learning as well as on the interplay of these dimensions.

In this sense, mobile learning has a lot to do with enabling awareness and becoming aware of interlaced contexts, and being able to deal with diverse forms of de- and re-contextualization as well as with modes of interaction and issues of framing. From a meta-theoretical perspective, reflexive forms of cognitive mobility or flexibility appear to be indispensable. In my opinion, helpful starting points are offered by a non-foundationalist approach as outlined by Goor, Heyting, and Vreeke (2004). It avoids arbitrary solution strategies by means of a threefold contextualization of specific problems and topics including reflection on meaning contexts, personal contexts and discourse contexts (cf. ibd., 176). The approach can be enhanced by reflections on user- and researcher-generated contexts. It offers undogmatic and dynamic orientation possibilities and it accommodates the undecidable character of many questions.

As for researching mobile learning, I see the following challenges in addition to requirements of dealing with the paradoxes and ambivalences mentioned above:

- Getting a sense of co-evolutionary developments and possibilities of fostering medial empowerment by encouragement of balancing acts between immersive and (self-)reflexive dynamics. This includes design principles for learning about interfaces, for example, of socio-cultural, informational and technological ecologies and providing educational materials for orientation and exploration at all levels.

- Concepts and practices for cultivating cognitive mobility through mediation between individual experiences and collective memories and combinations of critical, ecological, computational, emotional and design thinking in The Age of Surveillance Capitalism (Zuboff 2019).

- Understanding de-naturalization of media ecologies as well as embedded power structures in both dynamics of «naturalization〉 and 〈culturalization> of nested ecologies and mobilities. 
- Avoiding problematic tilt effects as related to dynamics of re-governmentalization in the name of de-governmentalization when criticizing techno-governmentality or «ecogovernmentality» (Luke 1999) and aiming at «ecowashing» mobile learning in analogy to «wikiwashing» (Fuster Morell 2011).

- Navigating between Scylla and Charybdis as related to contrary dynamics of digital inclusion and exclusion, not least in view of shortterm advantages at the cost of dependence and submission to technobureaucratic systems of surveillance.

Even though we consider the theoretical frameworks discussed as most promising candidates for useful paradigms for researching and designing mobile learning, complexities of corresponding projects should not be underestimated in view of ecologies and mobilities in flux.

\section{Conclusion}

Like commons, inclusion, sharing or Virtues of Openness (Peters and Roberts 2012), mobilities and ecologies are no values per se - they necessitate contextual considerations in various respects in order to act as differentiated paradigmatic perspectives and not as paradogmatic claims in service of a 3D-alliance in times of leverything 4.0), a 3D-alliance consisting of datafication, digitization and democracy management (Mausfeld 2018) suggesting only one innovation pathway towards growing dependence of all social, cultural, and educational developments on some technological developments. Correspondingly, future-oriented developments of educational media ecologies (Meister, Hug, and Friesen 2014) in general, and in particular for mobile learning require a differentiated approach to historical and contemporary narratives including approaches to discourse assessment (Diskursfolgenabschätzung by analogy to technology assessment). As is the case for all transformation processes in media societies, there is not just one innovation pathway of digital transformation (cf. Mansell 2018), there are many if any. This applies to mobile learning, too. 


\section{References}

Adolf, Marian. 2011. "Clarifying Mediatization: Sorting through a Current Debate». Empedocles: European Journal for the Philosophy of Communication 3 (2): 153-75. https://doi.org/10.1386/ejpc.3.2.153_1.

Aßmann, Sandra, Peter Moormann, Karina Nimmerfall, und Mirjam Thomann, Hrsg. 2017. Wenden. Wiesbaden: Springer Fachmedien Wiesbaden. https://doi. org/10.1007/978-3-658-14805-8.

Bachmair, Ben, Norbert Pachler, und John Cook. 2011. «Editorial. Mobile Learning Towards Curricular Validity in the Maelstrom of the Mobile Complex». MedienPädagogik: Zeitschrift für Theorie Und Praxis Der Medienbildung 19 (Mobile Learning), 1-6. https://doi.org/10.21240/mpaed/19/2011.07.09.X.

Berge, Zane L., und Lin Y. Muilenburg, Hrsg. 2013. Handbook of mobile learning. Florence, KY: Routledge.

Crompton, Helen. 2013. "A historical overview of mobile learning: Toward learner-centered education». In Handbook of mobile learning, herausgegeben von Zane L. Berge und Lin Y. Muilenburg, 3-14. Florence, KY: Routledge.

Fuster Morell, Mayo. 2011. "The Unethics of Sharing: Wikiwashing». 15. International Review of Information Ethics. http://www.i-r-i-e.net/inhalt/015/o15Morell.pdf.

Goor, Roel van, Frieda Heyting, und Gert-Jan Vreeke. 2004. «Beyond Foundations: Signs of a New Normativity in Philosophy of Education». Educational Theory 54 (2): 173-92. https://doi.org/10.1111/j.1741-5446.2004.00013.x.

Hörl, Erich, und James Burton, Hrsg. 2017. General ecology: the new ecological paradigm. Theory. London: Bloomsbury Academic, an imprint of Bloomsbury Publishing Plc.

Hug, Theo. 2015. «Microlearning and Mobile Learning». In Encyclopedia of Mobile Phone Behavior, herausgegeben von Zheng Yan, 1, 2 \& 3:490-505. IGI Global. https://doi.org/10.4018/978-1-4666-8239-9.

Krippendorf, Klaus. 1994. «Der verschwundene Bote. Metaphern und Modelle der Kommunikation». In Die Wirklichkeit der Medien: eine Einführung in die Kommunikationswissenschaft, herausgegeben von Klaus Merten, Siegfried J. Schmidt, und Siegfried Weischenberg, 79-113. Opladen: Westdeutscher Verlag.

Luke, Timothy W. 1999. "Environmentality as Green Governmentality». In Discourses of the environment, herausgegeben von Éric Darier. Oxford, UK; Malden, Mass., USA: Blackwell.

Mansell, Robin. 2018. Transformative Communication Technologies: The Accountability Challenge. Kleine Medienreihe, 2/2018. Innsbruck: innsbruck university press. https://www.uibk.ac.at/iup/buch_pdfs/9783903187146.pdf.

Mausfeld, Rainer. 2018. Warum schweigen die Lämmer? Wie Elitendemokratie und Neoliberalismus unsere Gesellschaft und unsere Lebensgrundlagen zerstören. Frankfurt am Main: Westend Verlag. 
Meister, Dorothee M., Theo Hug, und Norm Friesen, Hrsg. 2014. Educational Media Ecologies. Zürich: Zeitschrift MedienPädagogik 24. https://doi.org/10.21240/ mpaed/24.X.

Pachler, Norbert, Ben Bachmair, John Cook, und Gunther R. Kress. 2010. Mobile learning: structures, agency, practices. New York: Springer.

Peters, Michael A., und Peter Roberts. 2012. The Virtues of Openness: Education, Science, and Scholarship in the Digital Age. Interventions: Education, Philosophy \& Culture. Boulder, Colo.: Paradigm Publ.

Quinn, Clark. 2000. «mLearning. Mobile, Wireless, In-Your-Pocket Learning». Linezine, Nr. Fall 2000. http://www.linezine.com/2.1/features/cqmmwiyp.htm.

Rummler, Klaus. 2014. "Foundations of Socio-Cultural Ecology: Consequences for Media Education and Mobile Learning in Schools». MedienPädagogik: Zeitschrift für Theorie Und Praxis Der Medienbildung 24 (Educational Media Ecologies), 1-17. https://doi.org/10.21240/mpaed/24/2014.07.10.X.

Sharples, Mike, Josie Taylor, und Giasemi Vavoula. 2007. «A theory of learning for the mobile age». In The Sage Handbook of E-Learning Research, herausgegeben von Richard Andrews und Caroline Haythornthwaite, 221-47. London: Sage.

Sheller, Mimi. 2014. «The new mobilities paradigm for a live sociology». Current Sociology Review 62 (6): 789-811.

Sheller, Mimi. 2017. «From Spatial Turn to Mobilities Turn». Current Sociology 65 (4): 623-39. https://doi.org/10.1177/0011392117697463.

Sheller, Mimi, und John Urry. 2006. «The New Mobilities Paradigm». Environment and Planning A: Economy and Space 38 (2): 207-26. https://doi.org/10.1068/ a37268.

Urry, John. 2000. Sociology beyond societies: mobilities for the twenty-first century. International library of sociology. London; New York: Routledge.

Urry, John. 2012. "What is the mobility turn?» Mobile Lives Forum (blog). 2012. http://en.forumviesmobiles.org/video/2012/12/10/what-mobility-turn-467.

Vavoula, Giasemi, Norbert Pachler, und Agnes Kukulska-Hulme. 2009. Researching mobile learning: frameworks, tools, and research designs. Oxford; New York: Peter Lang.

Witt, Claudia de, und Christina Gloerfeld, Hrsg. 2018. Handbuch Mobile Learning. Wiesbaden: Springer Fachmedien Wiesbaden. https://doi.org/10.1007/978-3658-19123-8.

Zuboff, Shoshana. 2019. The Age of Surveillance Capitalism: The Fight for a Human Future at the New Frontier of Power. London: Profile Books Ltd. 